\title{
Timing of diapause in relation to the onset of winter in the high-latitude copepods Pseudocalanus acuspes and Acartia longiremis
}

\author{
M. Fredrika Norrbin* \\ The Norwegian College of Fishery Science, University of Tromsø, Breivika, N-9037 Tromsø, Norway
}

\begin{abstract}
It is proposed that the timing of overwintering diapause in multivoltine, marine copepods is optimised as in insects and limnic copepods. Theoretical models state that resting should begin a period equivalent to 1 generation before the environment becomes unfavourable. Computer simulations and field studies have shown this to apply to insects and limnic copepods. The present paper tests and discusses the model predictions in relation to seasonal environmental changes and life history events for populations of Pseudocalanus acuspes (Giesbrecht, 1881) and Acartia longiremis Lilljeborg in North Norwegian fjords. These copepods switch from developing populations, with normally developing gonads, to resting populations, with immature gonads, within a few weeks in early fall. Phytoplankton abundance and primary production decline later in the fall.
\end{abstract}

KEY WORDS: Dormancy Overwintering - Life history

\section{INTRODUCTION}

An important aspect of the adaptation of a multivoltine organism to a seasonal environment is the timing of the events of entering and coming out of a resting stage. Optimal timing can be achieved if the organism is able to respond to consistent environmental cues, i.e. proximate mechanisms, that trigger appropriate physiological or behavioural changes in its life history. These must be distinguished from the ultimate causes for selection (Mayr 1961) that have a direct influence on survival and reproduction. In a high-latitude pelagic system, winter represents a long period of food shortage. Optimal timing of life history events serves to minimise the impact of starvation on survival and fecundity of individuals.

In a variable environment, entering dormancy is a superior strategy when the expectancy of reproduction falls below the expectancy of survival for a dormant individual (Cohen 1970). Dormancy is essentially an alternative to dispersal (Levin et al. 1984) when local

•E-mail: fredrika@nfh.uit.no conditions become unfavourable; for plankton, however, migration is rarely an option. Taylor (1980) developed models for the optimisation of life histories in multivoltine species experiencing a seasonally occurring adverse period, or winter. The optimal strategy for a female would be to begin to produce resting eggs ca 1 generation before the predicted date of the catastrophe. Hairston \& Munns (1984) found evidence for optimal timing of diapause in populations of Diaptomus sanguineus (a limnetic copepod) exposed to a seasonally occurring elevated predation rate. Computer simulations showed that the switch to diapause began earlier when the variability in catastrophe date was high (Hairston \& Munns 1984, Hairston et al. 1985).

These models have not been used to explain seasonal patterns of marine copepods. In the marine pelagic environment, advection is believed to disrupt tendencies for adaptation on small geographical scales. Latitudinal differentiation in the response to day length as a trigger for resting egg production in Labidocera aestiva (Marcus 1984) demonstrates that this is not necessarily true. In North Norwegian fjords and the southern Barents Sea, copepod development and reproductive activity cease long before the autumn 
decline in primary production (Tande \& Hopkins 1981, Norrbin 1991, 1994). This could be triggered by rapidly changing day lengths in late summer. The aim of this paper is to test if these observations are consistent with the model of optimal timing of diapause outlined above.

For a stable strategy of diapause timing to persist, there must be a predictable onset of unfavourable conditions each year, differential survival of life history stages and a reliable environmental. cue. These criteria are discussed in relation to literature reports and field data on environmental parameters. The models presented by Taylor (1980) and Hairston \& Munns (1984) are tested using data on reproductive state and estimated development time for Pseudocalanus acuspes and Acartia longiremis from areas around Tromsø, northern Norway. The overwintering stages of $P$. acuspes consist of lipid-storing, copepodite Stages IV and $\mathrm{V}$ (and some Stage III) and in A. longiremis of fertilised females (Davis 1976). Both species overwinter in a state of 'active diapause' (sensu Elgmork 1980 and Næss \& Nilssen 1991), still feeding to some extent but with a considerably reduced metabolism (Norrbin 1994, unpubl. data).

\section{METHODS}

Description of the environment. Håkøybotn (Nordbotn) is a semi-enclosed bay SW of Tromsø, northern Norway $\left(69^{\circ} 40^{\prime} \mathrm{N}, 18^{\circ} 45^{\prime} \mathrm{E}\right.$; Fig. 1). Maximum depth of the bay is ca $55 \mathrm{~m}$ and the sill depth is 12 to $14 \mathrm{~m}$ (Holte \& Knutzen 1991), although much of the surrounding area is shallower. Environmental assessment studies (Oug \& Holte 1985, Holte \& Knutzen 1991) have shown that sediments are predominantly silty and anoxic in the deeper regions, and model simulations have shown water exchange in Håkøybotn to be especially poor, compared to the surrounding sounds and fjords that are flushed by tidal currents (Audunson \& Nceser 1975).

The sea surface temperature in Hảkoybotn and the Tromse region reaches a maximum of ca $12^{\circ} \mathrm{C}$ : in July or August, falls to 5 to $7^{\circ} \mathrm{C}$ by the middle of November, and drops to a minimum of 0 to $1^{\circ} \mathrm{C}$ in February (Oug \& Holte 1985, Holte \& Knutzen 1991, Normann 1991, 1993, present study). From mid-summer to late November day length decreases from 24 to $0 \mathrm{~h}$, with the most rapid change in day length during the transitions from midnight sun to alternating day and night (ca. 20 July), and to winter darkness (ca 20 November).

Sampling. Samples were collected weekly from late August 1989 to early November 1990 with a few exceptions, and from early August to late October in 1992 in the deepest part of Håkøybotn (Fig. 1). Zoo-
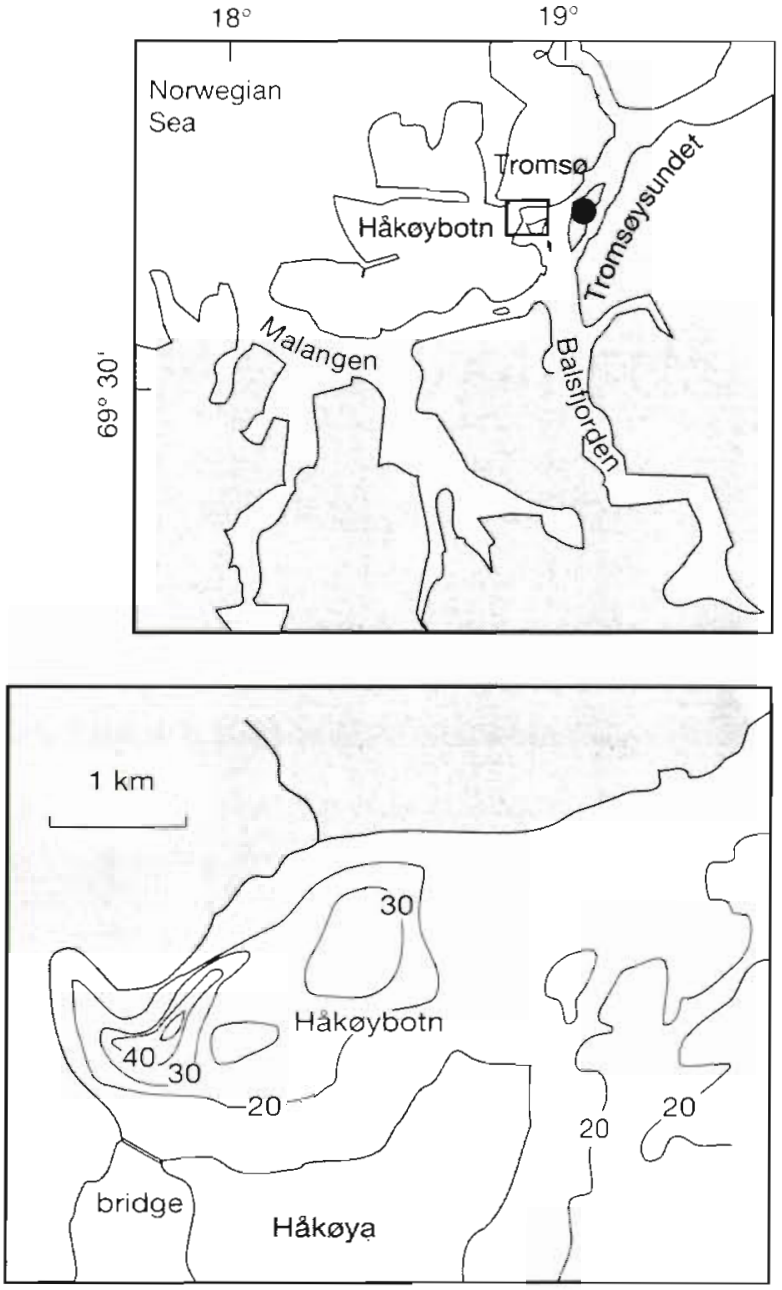

Fig. 1. Map of the sampling area in Hăkoybotn, Tromsø, and the surrounding fjords in Northern Norway. The sampling site is in the deepest part of Hákøybotn

plankton was caught using an $85 \mu \mathrm{m}$ modified WP-2net (UNESCO 1968; Nytal 15P mesh, diameter $=0.57 \mathrm{~m}$, total length $=3.45 \mathrm{~m}$, giving increased filtration area and flow through the mesh), towed vertically from bottom to surface at $0.25 \mathrm{~m} \mathrm{~s}^{-1}$ Water for chlorophyll cinierminations and phytoplankton counts was collected at $0,5,10,15,25$ and $40 \mathrm{~m}$ depth, using a $5 \mathrm{l}$ Niskin bottle. Temperature was measured in the sample water immediately upon its arrival on deck. In 1992, water samples were taken for chlorophyll measurements and at 5, 15 and $40 \mathrm{~m}$ depth for analysis of particulate carbon and nitrogen.

Laboratory treatment of samples. Zooplankton samples were preserved immediately in formaldehyde and propylene glycol ( 4 and $10 \%$, respectively). At least 100 copepodites of each species were counted in subsamples under a Wild Heerbrug dissecting microscope. Ca 25 copepods of each stage and sex to be 
analysed for gonad maturation were sorted out, stained in ethanolic borax carmine, dehydrated and placed in cedar oil (Norrbin 1991, 1994). Based on gonad maturation, Stage $V$ copepodites of Pseudocalanus acuspes were recorded as immature or maturing individuals. In $P$ acuspes copepodites, immature gonads are visible only as narrow strips, while maturing gonads are larger, with clearly visible gonoducts. Several maturity stages can be distinguished in Acartia longiremis females (Norbin 1994). In immature females, only the multiplication zone of the ovary is visible, but not the oviducts (1). During maturation, the ovary first develops, and extends somewhat anteriorly (II), followed by development of oocytes and oviducts (III). Reproductive females (IV) have a complete, differentiated reproductive system, mostly with mature eggs in the oviducts. Post-reproductive (V) is an intermediary stage between reproductive and senescent females (VI). In the latter stage, the distended oviducts remain visible, but diverticulae and ovaries have emptied and sometimes disintegrated. Fig 2 shows the frequency distribution of maturity stages during the height of the productive season.

For chlorophyll analyses, triplicate subsamples of 100 to $250 \mathrm{ml}$ were filtered onto $25 \mathrm{~mm}$ GF/C filters and stored in a cryofreezer at $-70^{\circ} \mathrm{C}$ until analysis. Filters were extracted in methanol and the chlorophyll a (chl a) concentration was measured using a Turner Design fluorometer Samples possibly damaged by a freezer malfunction (August 1990) have been excluded.

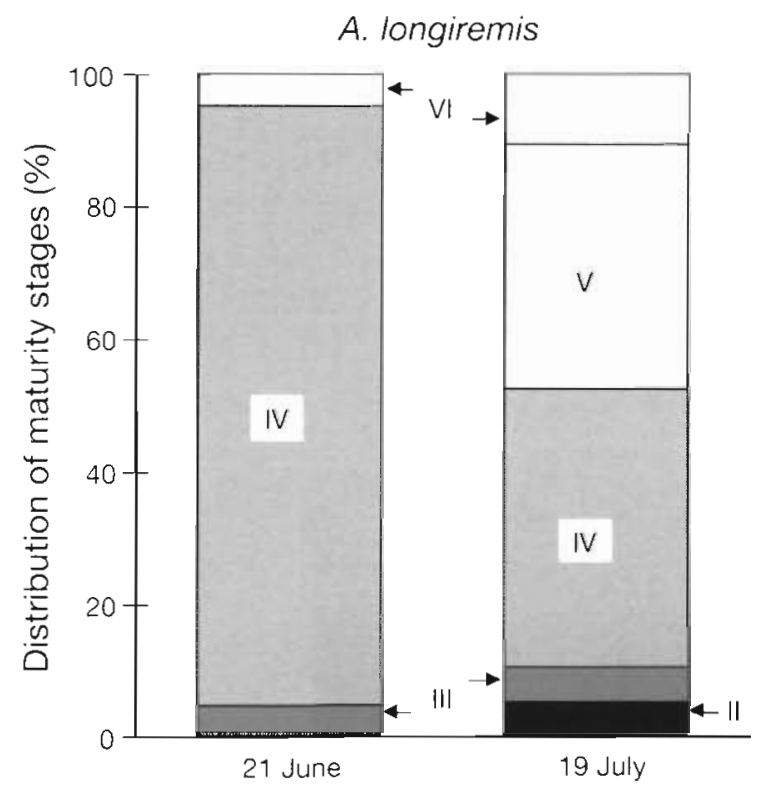

Fig. 2. Acartia longiremss. Distribution of maturation stages on 21 June and 19 July in 1990, showing the dynamics of the processes of maturation and senescence. The stages are described in the text
Samples for cell counts were preserved in Lugol's preservative. Subsamples were sedimented, and ca 100 cells counted in a Zeiss inverted microscope, to get an approximate estimate of the abundance and composition of phytoplankton taxa. Cell counts from 0,5 and $10 \mathrm{~m}$ are presented here. Particulate carbon and nitrogen was analysed using a 440 Elemental Analyzer from Control Equipment Corporation (Lowell, MA USA).

Embryonic duration. Estimates of hatching time were made during egg production measurements carried out in April 1991 (Norrbin 1992, unpubl. data) Adult females were collected in late March and fed a natural assemblage of food organisms. Water was collected below the surface and screened to remove eggs and small zooplankters. During the time of the incubations, in situ surface temperature varied from 3.5 to $4.1^{\circ} \mathrm{C}$. From 13 to 17 April, a total of 131 eggs were collected in Nunclon dishes and incubated at $3.3 \pm 0.11^{\circ} \mathrm{C}$ and $4.5 \pm 0.15^{\circ} \mathrm{C}$ (mean \pm standard deviation of daily temperature measurements]. Eggs were transferred to fresh sea water and the dishes checked for hatched eggs daily for $10 \mathrm{~d}$ and then weekly for another month.

Calculations of development time. Bělehrádek's function,

$$
D_{\Sigma}=a(T-\alpha)^{b}
$$

has been extensively used to describe embryonic duration of species of Pseudocalanus (e.g. Corkett \& McLaren 1978, McLaren 1978, McLaren et al. 1989) and Acartia (McLaren 1978) at conditions of adequate food. $D_{E}$ is time for embryonic duration, $\alpha$ is related to the normal temperature regime for the species, and $a$ is a population specific constant (Corkett \& McLaren 1978). The slope of the line is described by $b$, which is usually set to -2.05 for copepod species. With this parameter kept constant, measurements of embryonic duration must be made at a minimum of 2 temperatures in order to fit the function (Corkett \& McLaren 1978, p. 109). The parameters determined experimentally at one location are generally adequate to describe the embryonic development rate and even generation times over the entire range of distribution of a species (Corkett \& McLaren 1978, McLaren 1978). Development times to the various copepodite stages have been shown to be proportional to embryonic duration, provided there is adequate food (Corkett \& McLaren 1978), and the same multiplication factor can be used for different species of a genus.

Initial age of eggs in the hatching measurements was set to $12 \mathrm{~h}$. Hatching frequency was $82 \%$ for the higher temperature, and $84 \%$ for the lower temperature. Only eggs hatched within the first $10 \mathrm{~d}$ were included in the calculations. Embryonic duration was calculated as time for $50 \%$ hatch, and found to be $6.17 \mathrm{~d}$ at $3.3^{\circ} \mathrm{C}$ 
and $5.06 \mathrm{~d}$ at $4.5^{\circ} \mathrm{C}$. These data points were fitted to Bělehrádek's function using Statgraphics non-linear regression analysis

For total development time of Acartia longiremis, $D$ was set to $10.22 D_{E}$ for embryonic duration (Landry 1975 , McLaren 1978) and an additional 1.25DE was added for time to first reproduction (Corkett \& McLaren 1978, McLaren et al. 1989). For Pseudocalanus acuspes, the parameters determined by McLaren et al. (1989) for the development to first reproduction $\left(D_{\text {gen }}\right.$ ) for this species in Halifax (Nova Scotia, Canada) was used,

$$
D_{\text {gen }}=22591(T+12.59)^{-2.05}
$$

(or 11.59DE; McLaren et al. 1989).

Calculations were made in Matlab for Windows version $4.2 b$, and the Signal Processing Toolbox for Matlab, version 3.0 (The Mathworks Inc., Natick, MA, USA). Figures were drawn using Excel or Matlab for Windows and finished in CorelDraw, version 4.0.

\section{RESULTS}

\section{Phytoplankton, carbon and nitrogen}

There was a decline in chl a and phytoplankton cells from late summer to autumn in Håkøybotn (Fig. 3A). Total cell numbers averaged for the upper $10 \mathrm{~m}$ dropped below $10^{6}$ cells $\mathrm{l}^{-1}$ around 20 September and decreased to $10^{5}$ cells $\mathrm{I}^{-1}$ during the first half of November. Diatom populations declined rapidly in late September (1990) or late October (1989) and small flagellates replaced them as the dominant component of the phytoplankton. However, diatom populations moved deeper in the water column already in early September and many cells seemed empty, indicating senescent populations. Chlorophyll values in the surface layer $(0$ to $10 \mathrm{~m})$

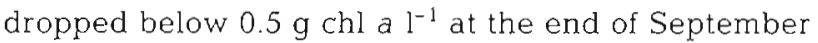
or early October (Fig. 3B).

At $40 \mathrm{~m}$ depth, the concentrations of particulate carbon and nitrogen were relatively constant from early August to late October in 1992, at ca $200 \mu \mathrm{g} \mathrm{C} \mathrm{I}^{-1}$ and ca $50 \mu \mathrm{g} \mathrm{N} \mathrm{I}^{-1}$, respectively (Fig. 3C, D). In late summer, the concentrations of these elements were about twice as high at $5 \mathrm{~m}$ depth, but dropped to the deep water values around 1 October. Levels at $15 \mathrm{~m}$ depth were intermediate.

\section{Zooplankton}

A maximum total abundance of about $1.1 \times 10^{5}$ ind. $\mathrm{m}^{-2}$ was reached in both species in late summer. In September, the population of Pseudocalanus acuspes became dominated by late copepodites but early copepodites persisted until mid-October (Fig. 4A). By this time, adults had almost disappeared from the population. The abundance at the end of October was 2 to $510^{4}$ ind. $\mathrm{m}^{-2}$. In Acartia longiremis, the 
A
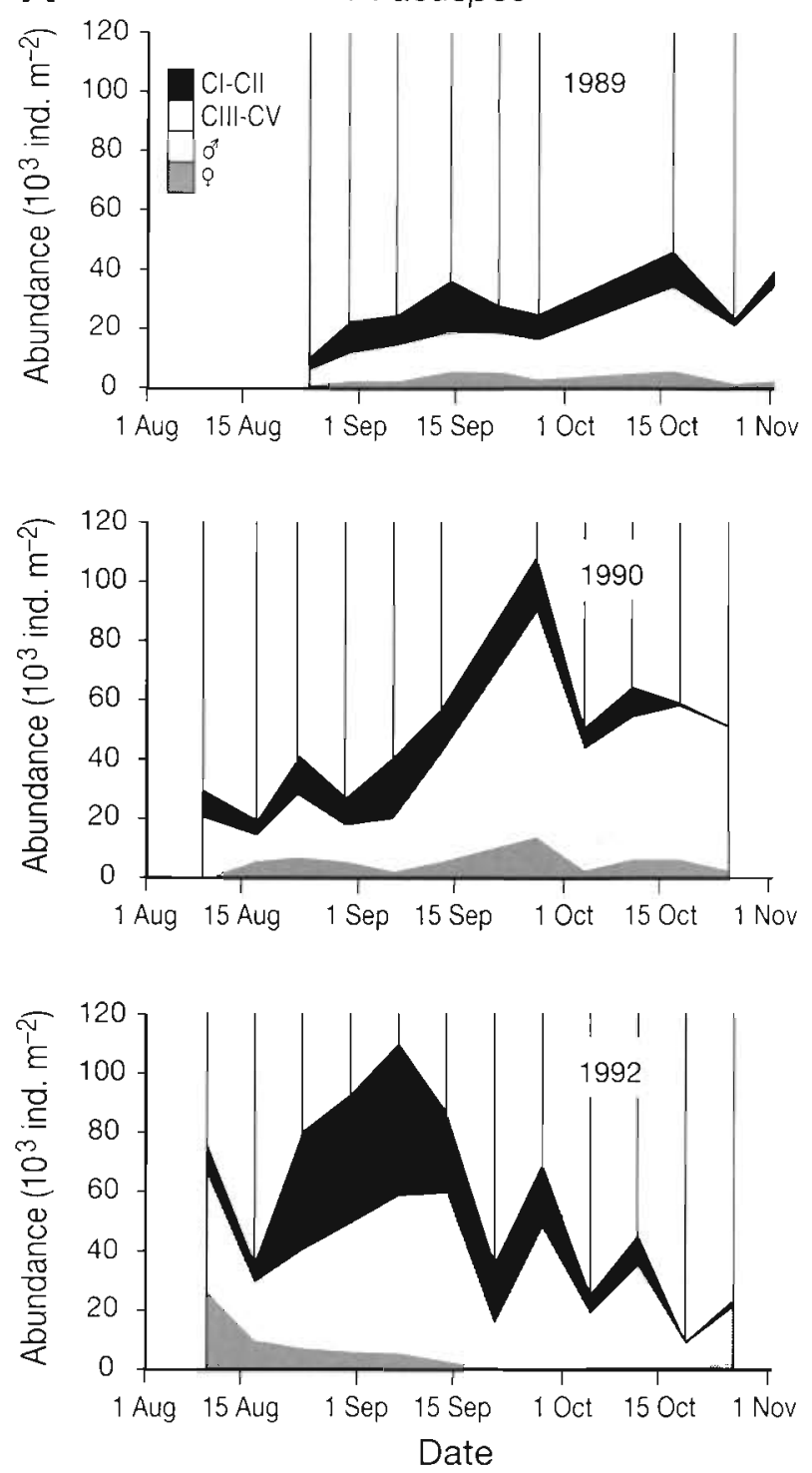

B
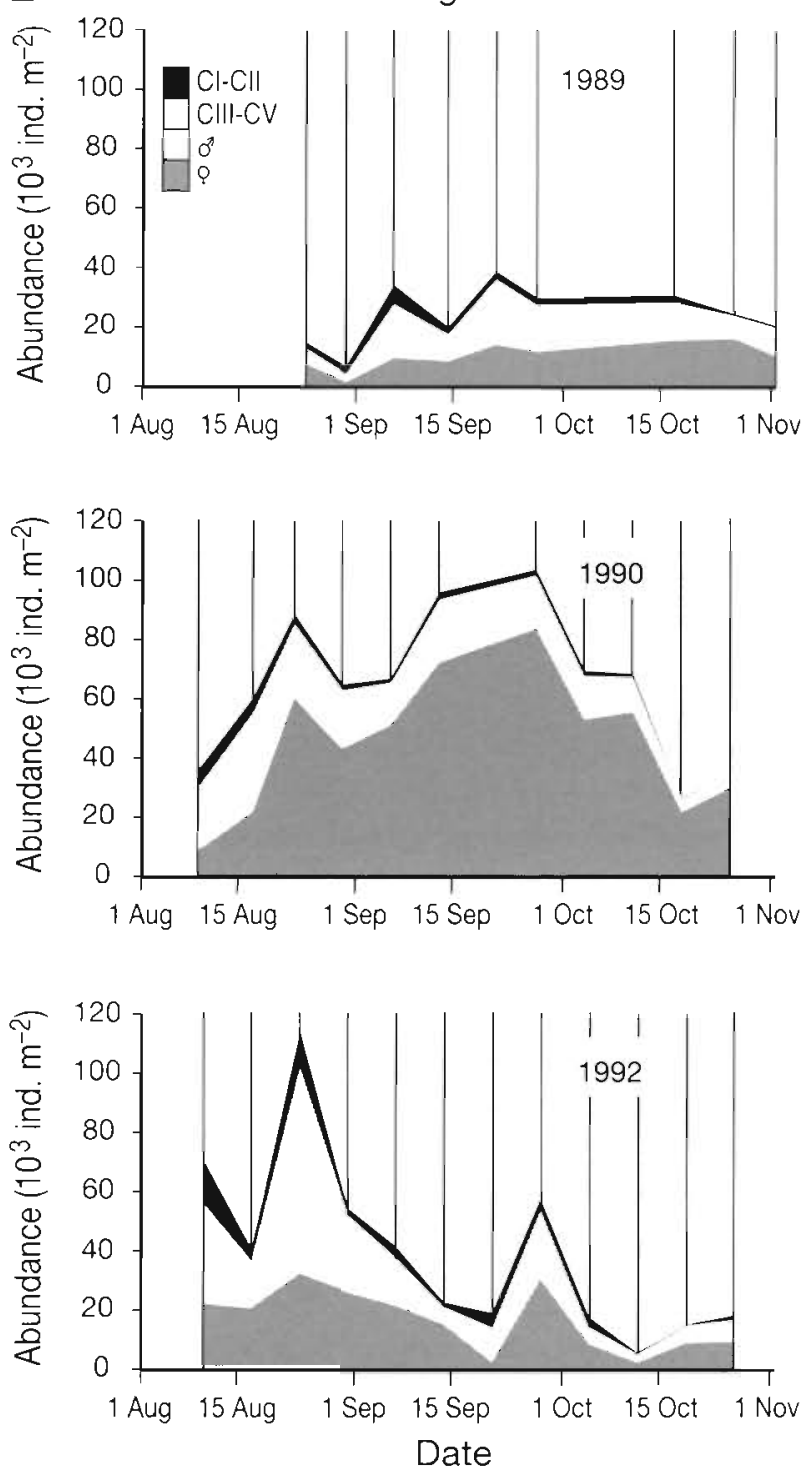

Fig. 4. Population development of small copepods in summer and fall, Håkoybotn 1989, 1990 and 1992. Vertical lines denote sampling dates. (A) Pseudocalanus acuspes. (B) Acartıa longiremis

number of early copepodites declined in late summer as adult females became dominant (Fig. 4B). Adult males were present during the whole period. The abundance of $A$. longiremis at the end of October varied from 2 to $3.5 \times 10^{4}$ ind. $\mathrm{m}^{-2}$ during the $3 \mathrm{yr}$ period.

A small percentage (usually $<5 \%$ ) of copepodites of both species were infected with Blastodinium all $3 \mathrm{yr}$. A heavier infection occurred in Acartia longiremis in 1990 , when more than $20 \%$ of the adult females were infected during summer. The parasites interfered with gonad development and ultimately filled most of the cephalothorax; these individuals were excluded from further gonad analysis.

\section{Embryonic duration}

The parameters of Bèlehrádek's function for Acartia longiremis were estimated to $a=1008$ and $\alpha=-8.701$. The resulting curve was close to that of $A$. clausi in Loch Striven, Scotland ( $a=1442, \alpha=-10.49$; McLaren 1978, based on data in Marshall 1949; Fig. 5).

\section{TIMING HYPOTHESIS}

Taylor's (1980) model for the optimal timing of diapause says that the optimal time to begin diapause corresponds to a period equal to the time from the dia- 


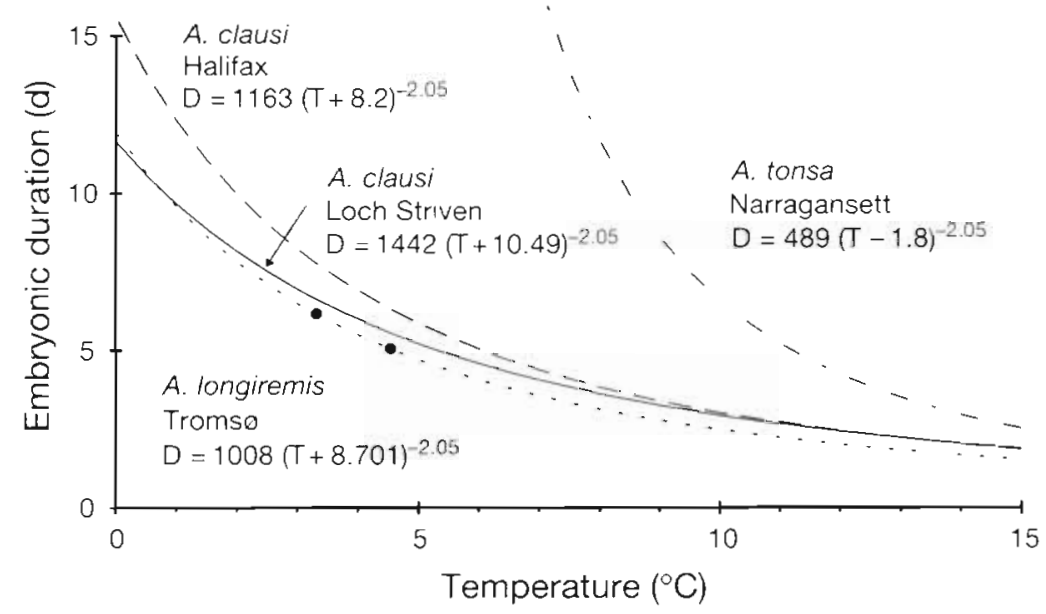

Fig. 5. Acartia spp. Temperature dependence of embryonic duration. Experimental results for $A$. longiremis in the present study were fitted to Bélehrádek's equation using non-linear regression analysis. Fitted curves are also shown for A clausi from Halifax, Nova Scotia, Canada (McLaren 1978), and Loch Striven, Scotland (Marshall 1949, in McLaren 1978), and for A. tonsa (Landry 1975)

pause stage to adulthood plus the time to produce 1 offspring that survives to diapause age. This means that, regardless of which life history stage is the dormant stage, diapause should begin at this stage, 1 generation before the actual catastrophe. If, however, the stage sensitive to the environmental trigger is other than the diapausing stage, development time between these stages should be added (Taylor 1980). In this study, the 2 stages are assumed to be equal (but see 'Discussion'). Acartia longiremis adult females, and Pseudocalanus acuspes copepodite Stage $V$, both sexes, were analysed with respect to resting gonads.

To test the timing hypothesis, the following information is needed (Hairston \& Munns 1984), and is discussed below: (1) information about the 'catastrophe' date; (2) developmental time, and time to produce 1 viable offspring; and (3) the actual switching date in the copepod populations.

\section{Determining catastrophe date}

The onset of winter for an insect as described by Taylor (1980) was set to the first hard frost. For the limnic copepod Diaptomus sanguineus, the seasonal catastrophe was the onset of heavy predation by sunfish (Hairston \& Munns 1984, Hairston et al. 1985). In high-latitude marine environments, the onset of winter is the time when the concentra- tion and quality of available food items is insufficient to support reproduction and development. All herbivorous or omnivorous copepods in these areas cease reproduction during a period in winter (Tande \& Hopkins 1981, Tande \& Gronvik 1983, Norrbin 1991). The overwintering stages of small copepods experience a reduction in abundance of $>90 \%$ of the population between November and March (Norrbin et al. 1990).

Although seasonal changes in the subarctic marine environment are abrupt, the time for the decline of available food in fall is not so simple to determine. Davis (1976) referred to a 'phytoplankton crash' in late October in Balsfjorden, Norway. A repeated pattern in North Norwegian fjords seems to be a rapid decline of diatoms in September, while solitary cells of Phaeocystis pouchetii and other flagellates still persist in high abundance (Gaarder 1938, Eilertsen et al. 1981, Bech 1982, Eilertsen 1983, Eilertsen \& Taasen 1984). Total cell numbers drop, but heterotrophic flagellates may remain in the water column throughout winter. Particulate organic carbon stays above $200 \mu \mathrm{g} \mathrm{Cl}^{-1}$ throughout the year (Eilertsen \& Taasen 1984), but the C:N ratio rises during October (Eilertsen \& Taasen 1984, present study), and bacterial. activity declines (Bech 1982). Several reports from areas around Tromse have been summarised in Fig. 6 , showing the decline in cell numbers, chl a, primary pro-

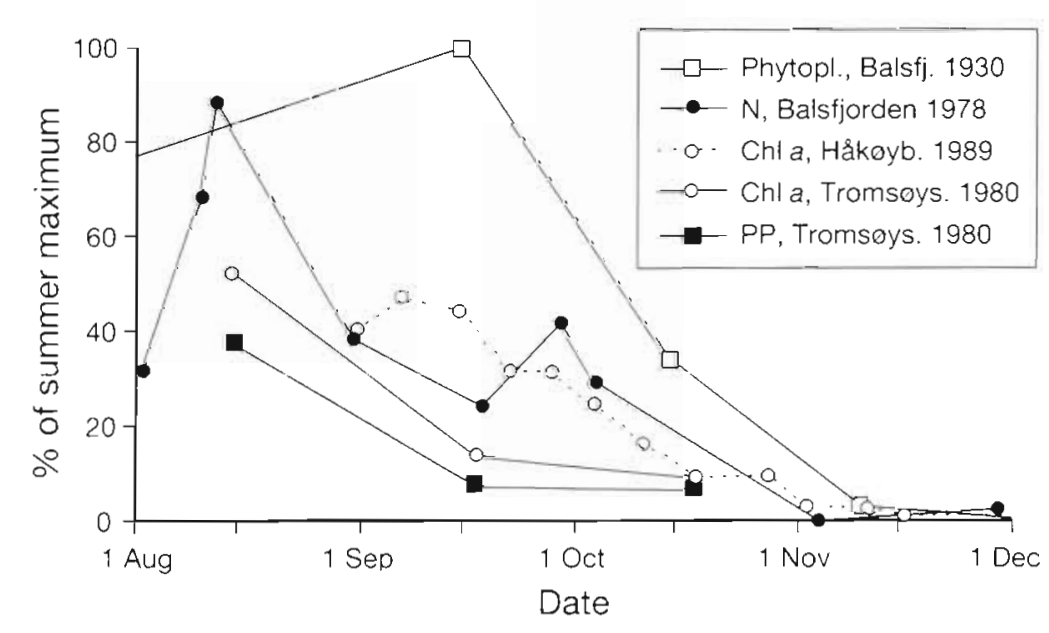

Fig. 6. Autumn decline in nutrients and the phytoplankton food source, North Norwegian fjords. Values are presented as percent of summer maximum, excluding spring bloom data, which were not always avallable. Phytoplankton counts have been averaged for 0 and $10 \mathrm{~m}$ depth, Balsfjorden (Gaarder 1938); $\mathrm{N}=$ nitrogen in Balsfiorden (Eilertsen \& Taasen 1984); chl a = chlorophyll a in surface layer of Tromsøysundet (Bech 1982) and from $5 \mathrm{~m}$ depth in Hakbybotn (present study); and PP = primary production in Tromsaysundet (Bech 1982) 
duction and particulate nitrogen in October Growth in the water column as a whole ceases when the day is too short for photosynthesis to balance respiration in phytoplankton. Field measurements (Eilertsen \& Taasen 1984), P/I experiments (Eilertsen et al. 1989a, b, Hansen et al. 1990), and model studies (Eilertsen et al. 1993, Hansen et al. 1993) show that the lower limit of net (particular) photosynthesis is 0.8 to $2.6 \mu \mathrm{E} \mathrm{m}^{-2} \mathrm{~s}^{-1}$ (measured using a cosinus collector). A daily scalar irradiance of $1 \mathrm{MW} \mathrm{m}{ }^{-2}$ corresponds to $2.16 \mu \mathrm{E} \mathrm{m}^{-2} \mathrm{~s}^{-1}$ (conversion factors for energy units and between the spherical and planar collectors from $\mathrm{H}$. C. Eilertsen pers. comm.). At sea level, this value is reached during the latter half of October and drops to zero irradiance ca 1 November (H. C. Eilertsen pers. comm.). Because nutritional requirements differ between copepod species, the exact catastrophe date may be species-specific. In this context, I operate with a single catastrophe date of 30 October, although possible deviations are considered in the 'Discussion'.

\section{Calculation of generation time}

Predicted dates for switching to diapause were estimated by calculating 1 generation backwards from selected catastrophe dates. Average temperature over the duration of a generation was used as input to Bělehrádek's equation. To determine generation span more realistically, an estimate of the natural betweenyear variation in temperature was needed. Temperatures measured during the $3 \mathrm{yr}$ of sampling were depth-integrated, averaged, and smoothed, using a zero-phase filter (Fig. 7). The $95 \%$ confidence interval of the mean temperatures for the 3 yr of sampling corresponded roughly to $\pm 1^{\circ} \mathrm{C}$. This range was added to the smoothed data set and used for calculations, so that the predicted switch date was actually a series of dates, ranging from minimum to maximum temperature conditions (Fig. 8).

\section{Predicted switching date}

The primary catastrophe date resulted in switching dates between 10 and 17 September for Pseudocalanus acuspes (Fig. 8A) and between 1.8 and 26 September for Acartia longiremis (Fig 8B). As a comparison, the predicted switching date for $A$. clausi would have been 13-21 September, using parameters estimated for a population at Loch Striven (Fig. 5; McLaren 1978).

\section{Switching date in field populations}

The time when $50 \%$ of the analysed life history stages were observed with immature gonads was used to indicate switching to diapause. The transition from a developing state to resting took place over a period of a few weeks. The proportion of resting Pseudocalanus acuspes copepodite Stage $V$ rose above $50 \%$ between 10 and 27 September during the 3 yr (Fig. 9A). The proportion of resting Acartia longiremis adult females increased in a less distinct pattern (Fig. 9B). The date when the immature population first rose above $50 \%$ was the last week in August 1990 and 1992, and ca 3 wk later in 1989. Each year, reproductive females lingered until late September (Fig. 9B), accompanied by a number of senescent females. A low number of $A$. clausi females found in the samples were persistently found to be reproductive when all $A$. longiremis were resting.

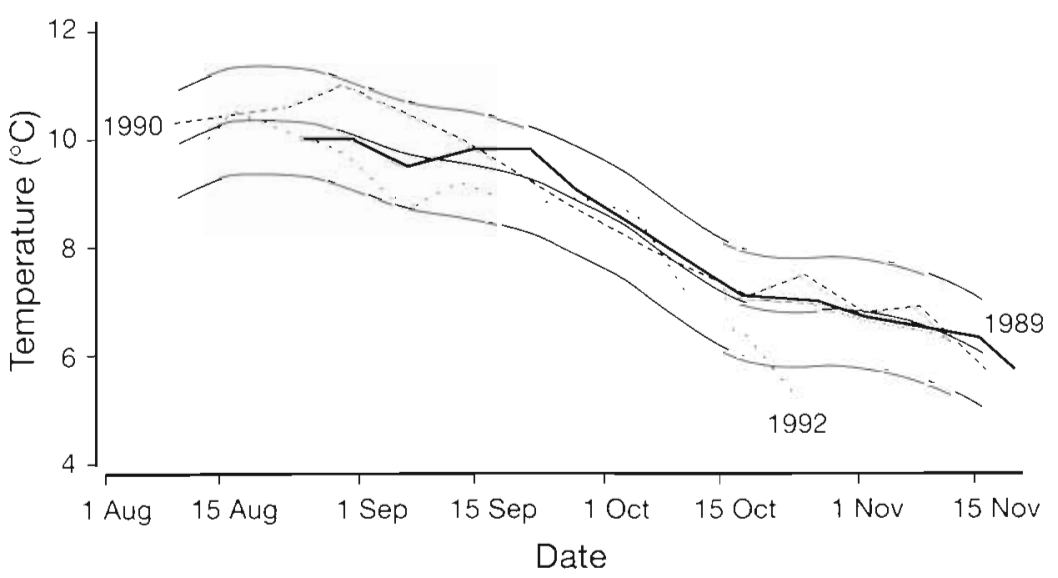

Fig. 7. Temperature data used for calculating copepod generation times. Smoothed temperature mean $\pm 1^{\circ} \mathrm{C}$ (see text). Depth-integrated temperatures from measurements taken in Hăkøybotn 1989 (solid line), 1990 (dashed line) and 1992 (dotted line) are also shown

\section{DISCUSSION}

\section{Correspondence between predictions and observations}

The time lag between the observed switch date and the onset of winter as defined above corresponds reasonably well with the theoretical period of 1 generation for Pseudocalanus acuspes but is less accurate for Acartia longiremis. Possible reasons for the observed deviations fall into the following categories: (1) the choice of catastrophe date is wrong; (2) the estimated generation time is wrong; (3) there is considerable interannual variability in the onset of winter; (4) the 

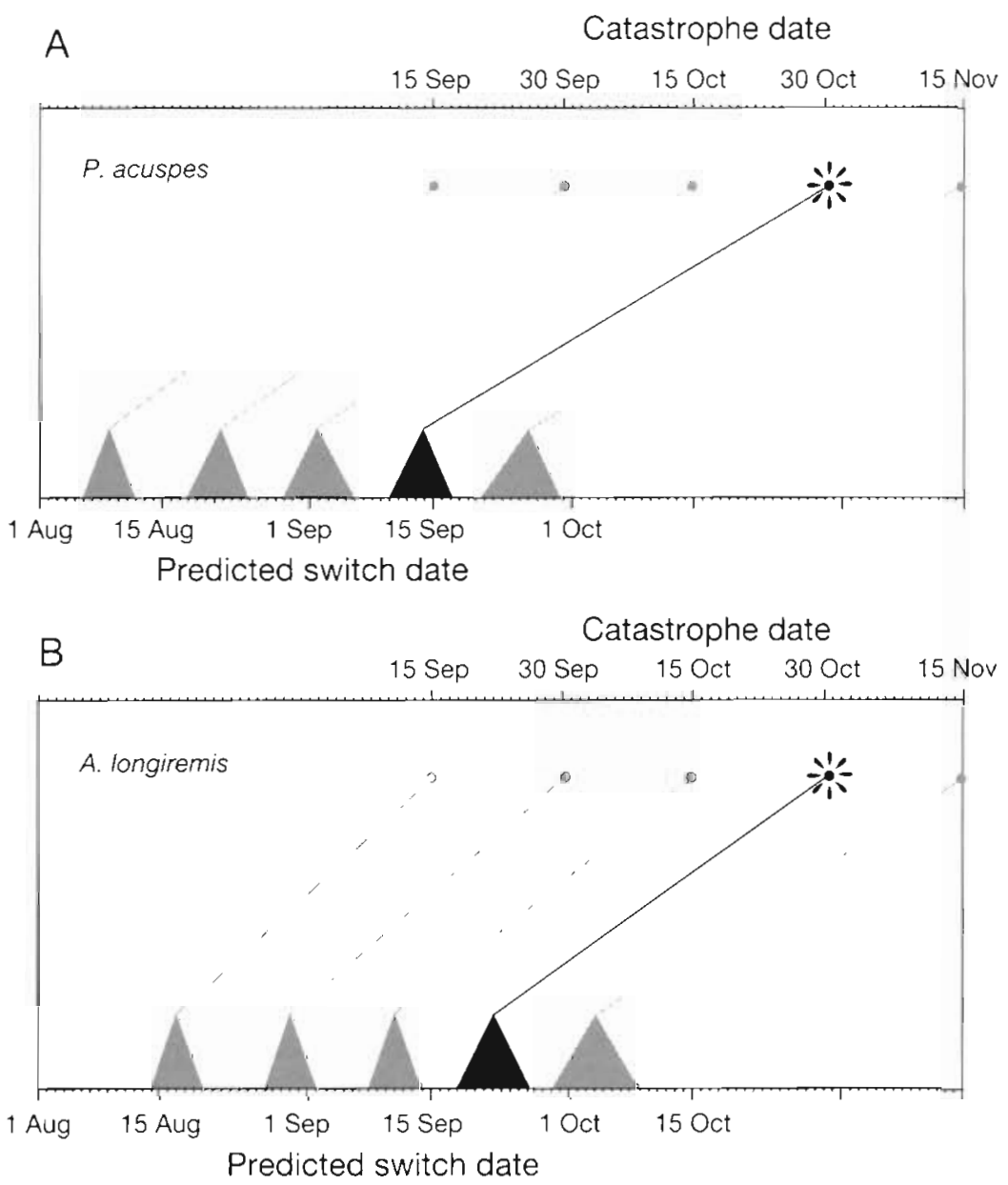

Fig. 8. Predicted dates for switching to diapause in (A) Pseudocalanus acuspes and (B) Acartia longiremis. Temperature-based generation time is calculated backwards from selected catastrophe dates (upper scale) to give predicted switching times. The primary catastrophe date (30 October) is indicated. The top of each triangle represents mean temperature conditions and the bottom of the triangle covers dates corresponding to the range of temperature conditions shown in Fig. 7

stage sensitive to the environmental trigger for diapause is other than the overwintering stage.

Pseudocalanus acuspes switched to diapause somewhat later than predicted from the catastrophe date. The deviation was ca $1 \mathrm{wk}$, corresponding to $15 \%$ of the calculated generation time or the duration of 1 developmental stage. A complication in the case of $P$. acuspes is that, instead of a single diapause stage, there is a range of overwintering stages (copepodite Stages IV and V, with some Stage III). According to Taylor's (1980) model, the switching time is based on the time to reproduce and produce offspring that reach diapause age, which could be interpreted as any of these stages. Thus, at a certain point in time, a copepodite Stage $V$ would have to weigh development through Stage IV in the next generation against beginning diapause immediately.
Acartia longiremis apparently made a slow switch to diapause, and a large part of the population continued reproducing for several more weeks. Because of the extended reproductive life span of A. longiremis females, the exact switching time is difficult to determine. Only recently moulted reproductive females are relevant to the estimation of switching time, but these cannot be easily separated from older reproductive females. Furthermore, the switch occurred almost a month earlier than predicted. It is likely that $A$. Iongiremis perceives the onset of winter to come earlier than 30 October, or to be less predictable, so that a more conservative switching strategy is in order. An earlier catastrophe date, such as 30 September, better predicts the observed switching time for this species (Fig. 8B)

\section{Effects of variability in seasonal changes of the environment}

According to computer simulations, unique switching strategies are appropriate only in continuously reproducing populations and only when the variability in a seasonal catastrophe date is low (Hairston \& Munns 1984). In contrast, populations with discrete generations cannot produce unique switching strageties of superior fitness. Also, if variability in the catastrophe date is high, copepods are forced to switch earlier to ensure long-term survival (Hairston \& Munns 1984). The between-year temperature variation in the present data set produces a standard deviation in catastrophe date corresponding to $8-10 \%$ of the generation time. Note also that Bĕlehrádek's equation, extended to whole generations, applies only when food is abundant (e.g. Corkett \& McLaren 1978). Thus, from the simulations of Hairston \& Munns (1984), switching times might be expected to be consistently earlier than the mean calculated date in Fig. 8.

Any superior strategy is maintained by selection in response to an average situation, and may be modified or replaced if there is a long-term change in that situation. If climatic conditions improve over several years, competing diapause strategies may emerge, since their success depends solely on survival when they are tested, each winter. 
A
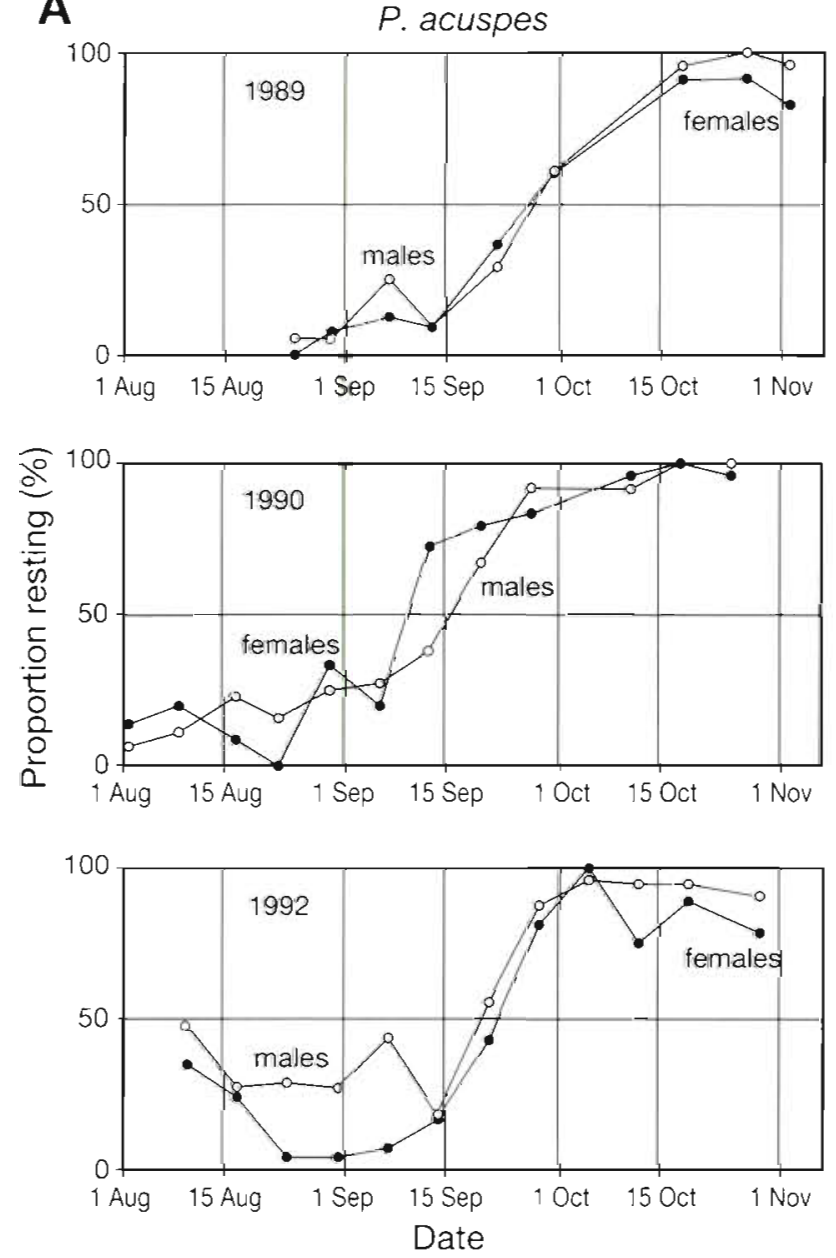

B
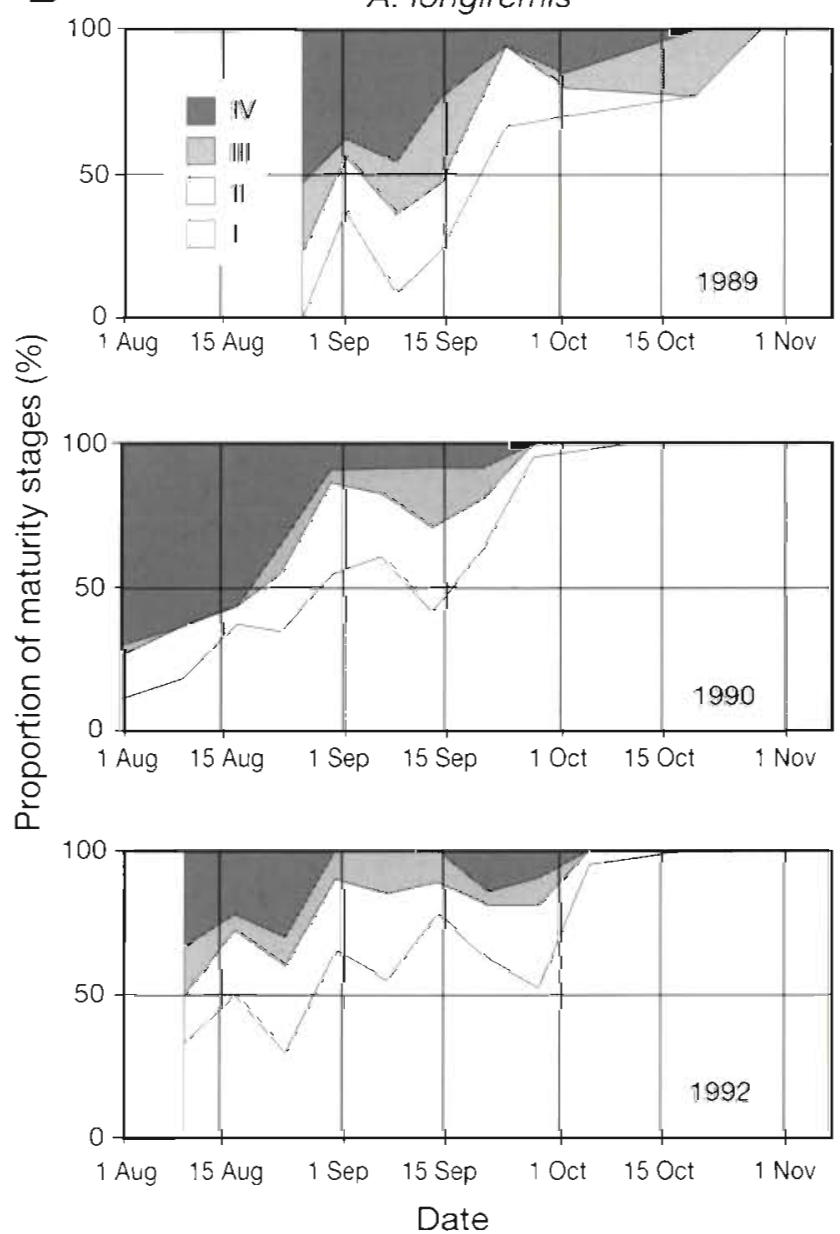

Fig. 9. Transition from a maturing population to a population dominated by diapausing individuals, Håkoybotn, August to October 1989, 1990, and 1992. (A) Pseudocalanus acuspes copepodite Stage V, males and females. Proportion of resting copepodites. (B) Acartia longiremis, adult females. Proportion of immature/reproductive females (maturation Stages I to IV), with post-reproductive and senescent females excluded

\section{Species-specific catastrophe dates and switching times}

There are good reasons to believe that Pseudocalanus acuspes and Acartia longiremis perceive environmental quality differently, and therefore switch to diapause at different times. Their separate overwintering stages are related to storage capabilities and specific patterns of energy allocation during ontogeny. Young A. longiremis copepodites are smaller relative to the adults than the corresponding stages of $P$. acuspes (Norrbin 1994), and store much less fat (Norrbin et al. 1990). Species of Acartia seem to require a more nutritious phytoplankton medium than other copepods (Paffenhöfer \& Stearns 1988), while Pseudocalanus spp. choose from a variety of living and detrital particles (Poulet 1976). The minimum carbon content required for completion of development is $100 \mu \mathrm{g} \mathrm{Cl}^{-1}$ for Acartia spp. and $50 \mu \mathrm{g} \mathrm{C}^{-1}$ for Pseudocalanus spp. (Vidal
1980, Klein Breteler et al. 1982, Berggreen et al. 1988). Small flagellates, and Phaeocystis pouchetii, which are common components of the phytoplankton in late autumn and winter in North Norwegian waters, are avoided by Acartia spp. (Parrish \& Wilson 1978, Verity \& Smayda 1989, Hansen et al. 1994), but not by Pseudocalanus spp. In the fjords around Tromsø, diatoms are replaced by small flagellates up to a month before the general collapse of primary production. This may explain the more conservative diapause switching date in $A$. longiremis compared to P. acuspes.

\section{Trigger mechanisms (environmental cues) and sensitive stages}

In both Pseudocalanus acuspes and Acartia longiremis, the trigger to prepare for diapause is likely to 
occur in a developmental stage before that which performs the switch. Hairston \& Munns (1984) pointed out that the best fitness is achieved for females that switch. from producing subitaneous to diapausing eggs near the optimal switch date, i.e. the sensitive stage is the same as the one performing the switch. A. longiremis females do not have that option, since the overwintering stage consists of females in which maturation of the reproductive system has not yet taken place. Taylor's (1980) model indicates that when the sensitive stage is an earlier stage than the diapause stage, the predicted switching date is in reality the date when diapause induction takes place, or 1 generation plus the intervening period to a diapausing stage. Assuming the sensitive stage is an early copepodite stage, induction occurs around 1 September in both species (Table 1) Unless we detect and analyse the switch directly in the sensitive stage, however, switching will still be observed in the diapausing stage at approximately the same date as described in Fig. 8. The most widely acclaimed proximate cue for seasonal behavioural and physiological changes for a range of organisms, including insects and copepods, is photoperiod (Tauber \& Tauber 1976, Marcus 1984, 1986). Day length has been shown to regulate the production of resting eggs (e.g Marcus 1980, 1986, Ban 1992), but experiments with diapause induction in copepodites have not been conclusive (Miller \& Grigg 1991). There is a rapid change in day length when the midnight sun period ends in late July in northern Norway. A photoperiodic response would be appropriate under these conditions.

\section{Conclusions}

This work has not conclusively determined diapause switching dates for Pseudocalanus acuspes and Acartia longiremis in North Norwegian fjords. However, the time frame of events makes an interpretation in

Table 1 Diapause induction (switching) dates, assuming difterent sensitive stages, and a catastrophe date of 30 October Calculations have been made as described for Fig. 8, but only the earliest, most conservative, switching date has been used. Isochronal development has been assumed for copepodite Stages I to VI in Acartia longiremis (McLaren 1978). Relative development times for Pseudocalanus acuspes have been estimated from data on this species and $P$. elongatus (Corkett \& McLaren 1978, McLaren et al. 1989)

\begin{tabular}{|c|c|c|c|}
\hline \multirow[t]{2}{*}{ Species } & \multicolumn{2}{|c|}{ Sensitive stage } & \multirow[t]{2}{*}{ Dlapausing stage } \\
\hline & C I & C III & \\
\hline P. acilspes & 27 Aug & 2 Sep & $10 \mathrm{Sep}$ \\
\hline A. longiremis & 2 Sep & 8 Sep & $18 \mathrm{Sep}$ \\
\hline
\end{tabular}

terms of evolutionary stable strategies of diapause timing plausible. Winter is an undisputable ultimate cause, and 2 separate species of copepods switch swiftly to resting states 6 to $8 \mathrm{wk}$ before the basis for primary production, day light, disappears. At the time necessary for induction of diapause, changes in day light provide a proximate cue that most organisms have the genetic potential to tune in to. There are no other theories that adequately explain the discrepancy between the primary productive season and copepod reproductive activity in fall.

Acknowledgements. I am greatly indebted to Tove Jacobsen, Astrid Hermansen and Jessica Marks for making most of the field collections and filtration, skilfully assisted by skipper G. Wagelid of RV 'Hyas' My sincere thanks to Bente Hauge and Britt Vaaja for analysing chlorophyll samples and counting cells. I am grateful to Hans-Christian Ellertsen for providing information about light and phytoplankton. Suggestions from the anonymous revewers helped to clarity several issues. This study was funded by the Norwegian Research Council for Science and the Humanities (NAVF), as a part of the research programme Mare Nor

\section{LITERATURE CITED}

Audunson T, Næerer $\mathrm{H}$ (1975) Investigations of sewage recipients near Tromsø. Vann 4:277-290 (in Norwegian)

Ban S (1992) Effects of photoperiod, temperature, and population density on induction of drapause egg production in Eurytemora affinis (Copepoda: Calanoida) in Lake Ohnuma, Hokkaido, Japan. J Crust Biol 12:361-367

Bech PA (1982) Phytoplankton and primary produktion in Ramfjorden and the Tromsøy sound. MSc thesis, University of Tromse (in Norwegian)

Berggreen U, Hansen B, Kiørboe T (1988) Food size spectra, ingestion and growth of the copepod Acartia tonsa during development: implications for determination of copepod production. Mar Biol 99:341-352

Cohen D (1970) A theoretical model for the optumal timing of diapause. Am Nat 104:389-400

Corkett CJ, McLaren [A (1978) The brology of Pseudocalanus. Adv Mar Biol 15:1-231

Davis CC (1976) Overwintering strategies of common planktonic copepods in some North Norway fjords and sounds. Astarte 9:37-42

Eilertsen HC (1983) Phytoplankton before and after the water regulation in Skjomen 1969-1.972 and 1977-1979. Consul. tative Committee for Fjord Investigations, The Skjomen project, Report No. 4, Oslo (in Norwegian)

Eilertsen HC, Hansen GA, Svendsen $H_{1}$ Hegseth EN (1993) The onset of the spring phytoplankton bloom in the Barents Sea: influence of changing light regime and other environmental factors. In: Eilertsen HC (ed) Underwater light measurements. SPIE Proc 2048:20-32

Eilertsen HC, Schei B, Taasen JP (1981) Investigations on the plankton community of Balsfjorden, northern Norway. The phytoplankton 1976-1978. Abundance, species composition, and succession. Sarsla 56:129-141

Eilertsen HC, Taasen JP (1984) Investigations on the plankton community of Balsfjorden, northern Norway. The phytoplankton 1976-1.978. Environmental factors, dynamics of growth, and primary production. Sarsia 69:1-15 
Eilertsen HC, Tande KS, Hegseth EN (1989a) Potential of herbivorous copepods for regulating the spring phytoplankıon bloom in the Barents Sea. Rapp PV Réun Cons Int Explor Mer 188:154-163

Eilertsen HC, Tande KS, Taasen JP (1989b) Vertical distrlbutions of primary production and grazing by Caldnus glaclalis Jaschnov and C. hyperboreus Kroyer in arctic waters (Barents Sea). Polat Biol 9:253-260

Elgmork K (1980) Evolutionary aspects of diapause in freshwater copepods. In: Kerfoot WC (ed) Evolution and ecology of zooplankton communities. Am Soc Limnol Oceanogr Spec Symp 3. The University Press of New England, Hanover, NH, p 411-417

Gaarder KR (1938) Phytoplankton studies from the Tromso district 1930-31. Tromsø Museum Årshefter, Naturhistorisk avdeling $11,55(1): 1-159$

Hairston NG JI, Munns WR Jr (1984) The timing of copepod diapause as an evolutionary stable strategy. Am Nat 123 $733-751$

Hairston NG Jr, Olds EJ, Munns WR Jr (1985) Bet-hedging and environmentally cued diapause strategies of diaptomid copepods. Verh Int Verein Limnol 22:3170-3177

Hansen B, Berggreen UC, Tande KS, Eilertsen HC (1990) Post-bloom grazing by Calanus glacialis, C. finmarchicus and $C$. hyperboreus in the region of the Polar Front, Barents Sea. Mar Biol 104:5-14

Hansen B, Verity P, Falkenhaug T, Tande KS, Norrbin MF (1994) On the trophic fate of Phaeocystis poucheti (Harriot) V. Trophic relationships between Phaeocystis and zooplankton: an assessment of methods and size dependence. J Plankton Res 16:487-51 1

Hansen Git, Eilertsen HC, Hegseth EN, Henriksen K (1993) On the submarine light field in a phytoplankton model. In: Eilertsen HC (ed) Underwater light measurements. SPIE Proc 2048:168-171

Holte B, Knutzen J (1991) Investigations of marine sewage recipients in Nordbotn, Sandnessundet and at Orndalen. Tromsø 1990. Benthos, hydrography and pollutants Report. The Norwegian Institute for Water Research. Oslo (ın Norwegian)

Klein Breteler WCM, Fransz HG, Gonzalez SR (1982) Growth and development of four calanoid copepod species under experimental and natural conditions. Neth J Sea Res 16 : 195-207

Landry MR (1975) The relationship between temperature and the development of life stages of the marine copepod Acartia clausi Giesbr. Limnol Oceanogr 20:854-857

Levin SA, Hastings A, Cohen D (1984) Dispersal strategies in patchy environments. J Theor Biol 60:301-335

Marcus NH (1980) Photoperioduc control of drapause in the marine calanoid copepod, Labidocera aestiva. Biol Bull Mar Biol Lab, Woods Hole 158:311-318

Marcus NH (1984) Variation in the diapause response of Labidocera aestiva (Copepoda: Calanoida) from different latitudes and its importance in the evolutionary process. Biol Bull Mar Biol Lab, Woods Hole 166:127-139

Marcus NH (1986) Population dynamics of marine copepods: the importance of photoperiodism. Am Zool 26:469-477

Marshall SM (1949) On the biology of the small copepods in Loch Striven. J Mar Biol Ass UK 28:45-95

Mayr E (1961) Cause and effect in biology. Science 134 $1501-1506$

McLaren IA (1978) Generation lengths of some temperate marine copepods: estimation, prediction and implications. J Fish Res Bd Can 35:1330-1342

McLaren IA, Sévigny JM. Corkett CJ (1989) Temperature- dependent development in Pseudocalanus species. Can J Zool 67:559-564

Miller CB, Grigg $H$ (1991) An experimental study of the resting phase in Calanus finmarchicus (Gunnerus). Proc 4th Int Conf Copepoda. Bull Plankton Soc Japan Spec Vol, p $479-493$

Nass T, Nilssen JP (1991) Diapausing fertilized adults: a new pattern of copepod life cycle. Oecologia 86:368-371

Normann U (1991) Ocean monitoring in North Norwegian fjords 1990. Norwegian Institute of Fisheries and Aquaculture Ltd, and The Norweglan College of Fishery Science, Tromsø (in Norwegian)

Normann U (1993) Ocean monitoring in North Norwegian fjords 1992. Norwegian Institute of Fisheries and Aquaculture L.td, and The Norwegian College of Fishery Science, Tromso (1n Norwegian)

Norrbin MF (1991) Gonad maturation as an indication of seasonal cycles for several species of small copepods in the Barents Sea. In: Sakshaug E, Oritsland NA (eds) Pro Mare Symposium on Polar Marine Ecology 1990. Polar Res 10:421-433

Norrbin MF (1992) Overwintering strategies of small copepods from high latitude marine environments. Dissertation. University of Gothenburg

Norrbin MF (1994) Seasonal patterns in gonad maturation, sex ratio and size in some small, high latitude copepods implications for overwintering tactics. J Plankton Res 16 $115-131$

Norrbin MF, Olsen RE, Tande KS (1990) Seasonal variation in lipid class and fatty acid composition of two small copepods in Balsfjorden, northern Norway. Mar Biol 105:205-211

Oug E. Holte B (1985) Recipient study in Nordbotn, Kvaløya 1983-84. Hydrography and benthos. TROMURA, Naturvitenskap No. 48, Institutt for Museumsvirksomhet, University of Tromso (in Norwegian)

Paffenhöfer GA. Stearns DE (1988) Why is Acartia tonsa (Copepoda: Calanoida) restricted to nearshore environments? Mar Ecol Prog Ser 42:33-38

Parrish KK, Wilson DF (1978) Fecundity studies on Acartıa tonsa (Copepoda: Calanoida) in standardized culture. Mar Biol 46:65-81

Poulet SA (1976) Feeding of Pseudocalanus minutus on living and non-living particles. Mar Biol 34:117-125

Tande KS, Gronvik S (1983) Ecological investigations of the zooplankton community of Balsfjorden, northern Norway: sex ratio and gonad maturation cycle of Metridia longa (Lubbock). J Exp Mar Biol Ecol 71:43-54

Tande KS, Hopkins CCE (1981) Ecological investigations of the zooplankton community of Balsfjorden, northern Norway: the genital system in Calanus finmarchicus and the role of gonad development in the overwintering strategy Mar Biol 63:159-164

Tauber MJ. Tauber CA (1976) Insect seasonality: diapause maintenance, termination, and postdiapause development A Rev Entomol 21:81-107

Taylor F (1980) Optimal switching to diapause in relation to the onset of winter. Theor Populat Biol 18:125-133

UNESCO (1968) Zooplankton sampling. Monographs on oceanographic methodology 2. Imprimerie Rolland, Paris

Verity PG, Smayda TJ (1989) The nutritional value of Phaeocystis (Prymnesiophyceae) and other phytoplankton for Acartia (Copepoda): ingestion, egg production, and growth of nauplii. Mar Biol 100:161-171

Vidal J (1980) Physioecology of zooplankton. I. Effects of phytoplankton concentration, temperature, and body size on the growth rate of Calanus pacificus and Pseudocalanus sp. Mar Biol 56:111-134

Manuscript first received: September 21, 1995

Revised version accepted: June 27, 1996 